\title{
Assessing the Impact of IT Connectivity and IT Capability on IT-Business Strategic Alignment: An Empirical Study
}

\author{
Saeid Jorfi (Corresponding author) \\ $\mathrm{PhD}$ student in IT Management, Universiti Technologi Malaysia (UTM), Malaysia \\ DO6- Postgraduate Office (FPPSM) - Management Faculty \\ Skudi- Johor Baharu. 81310- Johor- Malaysia \\ Tel: 60-1-7612-1137 E-mail: jsaeid2@live.utm.my
}

Khalil Md Nor

Associate professor, Universiti Technologi Malaysia (UTM), Malaysia

DO6- Postgraduate Office (FPPSM) - Management Faculty

Skudi- Johor Baharu. 81310- Johor- Malaysia

Tel: 60-1-7612-5344Ｅ-mail: kmdnor@fppsm.utm.my

Lotfi Najjar

Associate professor, University of Nebraska at Omaha ,USA

PKI 174-F. 1110 South 67 St. Omaha, NE 68182. USA

Tel: 1-402-554-2233Ｅ-mail: lnajjar@unomaha.edu

Received: January 14, 2011

Accepted: April 17, 2011

doi:10.5539/cis.v4n3p76

\begin{abstract}
Aabstract
The literature argues that organizations cannot be competitive if their business and information technology strategies are not aligned. Yet achieving strategic alignment continues to be a main concern for business executives. So this research seeks to address the research problem of the lack of alignment between IT strategy and business strategy. Past studies have shown that flexibility in IT is an influential aspect of sustaining strategic alignment in today's environment while researches on dimensions of IT flexibility regarding strategic alignment are limited. One of the most important dimensions of IT flexibility is connectivity which the research has considered this dimension. Further, the researchers have found that IT capability in regard to strategic alignment and IT connectivity has been ignored in the prior studies. Thus, this research for filling this gap proposed and empirically assessed the relationships among IT connectivity, IT capability, and strategic alignment. Data for this study were collected through questionnaires filled up by IT managers of organizations in United Arab Emirates. The findings indicated IT connectivity and IT capability have a significant positive effect on strategic alignment and IT connectivity has also a positive impact on IT capability.
\end{abstract}

Keywords: IT-business strategic alignment, IT connectivity, IT capability

\section{Introduction}

As Grembergen and Haes (2009) observed, IT and its use in business settings have undergone drastic changes in the past few decades. The developments of the late 1990s in the domain of IT had changed business environments worldwide (Frederick Betz, 2001). The majority of industrial, commercial, and governmental bodies essentially, became reliant on their IT systems. In Rockart's words, as indicated by Ward and Peppard (2002, p.1), "(i)nformation technology has become inextricably intertwined with business." Currently, IT is put to use pervasively in organizations that could result in protracted advantages in competitive settings.

The question then crops up as to what position is played by IT in the success of an organization's strategic objectives and goals. Replying to this, Venkatraman et al. (1993) and Franz and Klepper (1995) suggested that the critical function of IT is very often characterized as a match or in association with the strategic aims of the organization. A factor that increasingly worries organizations and the management of IT is and continues to be 
IT positioning in line with strategic aims (Galliers, 1993; CSC, 2001). A very apparent fact in literature is the function of strategic positioning among IT and business policies as a vital part of an organization's performance (Brown, 2004; Kearns and Lederer, 2001) and competitive advantage (Grant, 1991). This strategic alignment between IT and business goals has proved to enhance organizational efficacy (Chan and Huff, 1993), get the most out of return on investment (Feidler, Gorver and Teg, 1995), enable organizations to improve on managing their business needs on the whole, technology, and rivals (Boar, AT and T Bell Laboratories, 1994) and offer stability in a company (Labovitz and Rosansky, 1997). According to Piccoli and Ives (2005), organizations such as Harrah's Entertainment, Wal-Mart, and Dell have gained tremendously by aligning their IT strategies accurately with their own business strategies.

Even though strategic alignment between IT and business has brought many benefits as mentioned above, there are severe challenges confronted when sustaining strategic alignments in business setups during these times. Changes in business strategies are one of the primary challenges confronted by organizations to sustain strategic in this active and unstable business settings (Luftman, Papp, and Brier, 1999). Events like price wars, decrease in demand, new product launched by a competitor can change business strategies as expressed by Mendelson and Pillai (1998). A more flexible IT or IT that has the ability to meet business changes is very crucial to sustain strategic alignment in business environments today (Bharadwaj, 2000). Connectivity as an important aspect of IT flexibility is considered in this paper. Moreover, reviewing the respective literature indicated that IT capability has been ignored with regard to strategic alignment that based on available literature and strong arguments we can propose a significant relationship between IT capability and strategic alignment.

\section{IT - Business Strategic Alignment}

Given the speed with which breakthrough technologies are emerging within the domains of IS and IT, newer opportunities are opening up through the implementation of strategic technology and making advantages available to organizations and businesses (Galliers and Leidner, 2003). The strategic employment of IT and IS has become critical for every business since this enables organizations to alter the basic nature of industries. Their efficient and impact worthy utilization necessitates alignment of the IS/IT strategies with business strategies, business plans, and constant continuous execution for improvement in competitiveness and enhanced productivity. This can be brought about by enhancing the core business processes and making use of opportunities opened up by redesigning the business processes (Luftman, 2000). Although strategic alignment is not new as a concept, it is still valuable for creating alignment of business and technological strategies (Coleman and Papp, 2006; Ward and Peppard, 2002).Strategic alignment is critical for achieving continued competitive advantages for any industry. The strategic and successful use of IT is well reflected through the concept of strategic alignment. There are a number of definitions to this concept stated by scholars, for example, Reich and Benbasat (2000) defined strategic alignment as "the degree to which the IT mission, objectives and plans support and are supported by the business mission, objectives and plans".

\section{Connectivity (as a dimension of IT flexibility)}

IT flexibility, according to Mensah (1989), is "the ability to respond and adapt to changing business conditions both within and outside the organization." Ness (2005) studied IT flexibility i.e. connectivity, compatibility, and modularity with relation to strategic alignment. Due to the importance of connectivity as stated by researchers (e.g., Chung et al., 2003) this research focused on this dimensions of IT flexibility.

The number of platforms that a business entity can hook up to is symbolized as connectivity (Duncan, 1995; Tallon and Kraemer, 2003c). In the application of the term "reach," connectivity formerly emerges to have been resulting from the study by Keen (1991). It involves the number of locations to which the platforms or technology can link to, or can be connected. This ideology was confirmed by Goldman, Nagel, and Preiss (1995), when suppleness was considered a way of competition and facilitation of the virtual organization. Additionally, connectivity was identified by E-sourcing (2002) as a means of delivering IT on demand (e.g., IT flexibility). As an example, Blodgett (2004) mentioned how Intelsat underwent a fundamental and brisk alteration to a for profit organization offering network connectivity for enterprises globally. In order to assist with the coordination of the fierce construction demands, it required an incorporated systems infrastructure. To gain more time effective and reliable data, IT built a data warehouse as part of a Business Intelligence (BI) project. The system was built in only three months and the organization achieved US\$ 150 million in possible, existing satellite capacity and US\$ 3 million of income via enhanced billing and receivables. A good example for both connectivity and as shall be discussed, modularity, is provided by Enterprise Application Integration (EAI) software. EAI is dealt with individually from other components. Enhanced flexibility is offered through the ability of managing data routing and transformation between components more efficiently (Altman and Altman, 2004). For example, the 
overall architecture is less rigid and has comparatively less built in dependencies if the integration layer is separated from the application layer. It also enables changes to be made faster and with less risk. In general, when a technological component is capable of coordinating and communicating with any other component within the establishment as well as with the external environment, this is defined as connectivity (Duncan, 1995). It has been stressed by Tapscott and Caston (1993) that with IT connectivity, organizations that are flawless and transparent are able to be free from the influence of time and space. It is much easier to share IT resources at the platform level with connectivity.

\section{Literature review on the link between IT flexibility (focus on connectivity) and Strategic Alignment}

According to Teece, Pisano, and Shuen (1997) IT flexibility has an influence on strategic alignment. Weill, Subramani, and Broadbent (2002) also suggested the importance of IT flexibility in relation to strategic alignment and mentioned that "defender" (Miles and Snow, 1978), or establishments that lacked IT flexibility, encountered a more demanding time when obtaining business value from strategic alignment. Another study was carried out by Chan et al. (1997) where they noticed a strong association between increasing innovation levels of IT flexibility and strategic alignment.

Tallon (2009) studied six case studies in a variety of industries like aerospace, financial services, occupational services, health coverage, publishing, and software. These industries substantiate the complication of the results. This helped him to identify a favourable association between IT infrastructure flexibility and strategic alignment. Strategic information systems planning (SISP) acts as a mediator in this relationship.

Chung et al. (2003) scrutinized the influence of the four components of IT infrastructure flexibility (compatibility, connectivity, modularity, and IT personnel) on strategic IT-business alignment. They compiled data from 200 U.S. and Canadian companies. The results from the examination of a formational model offer evidence that connectivity, modularity, and IT personnel have a noteworthy effect on strategic alignment. Additionally, the data confirmed that IT connectivity has a stronger relationship with strategic alignment than do other dimensions.

\section{IT capability}

Enterprises consist of many different types of complex situations that are intertwined in an active and dynamic environment. IT capability makes it easier for companies to gain the upper hand over competitors and simultaneously, become one of the most vital sources for the enterprise. From the many studies undertaken, mainly from the United States and some of the Western countries (Tippins and Sohi, 2003), it has been found that in the $21^{\text {st }}$ century, IT capability is a crucial resource for enterprises (Bharadwaj and Been, 1999).

In one of the researches (Lee et al., 1999), IT capability is defined as a type of ability organizations have that can support the activities and work processes in the organization by arranging and bringing together other resources that are important. In another study (Bharadwaj, 2007), IT capability is described as the ability that can incorporate other resources of organizations through the usage and allocation of IT resources. According to Bharadwaj (2007), IT resources can be split into three groups, which are IT intangible assets, IT infrastructure, and IT human resources. Qingfeng and Daqing (2005) pictured IT capability as a multidimensional construct. When literature related to IT was examined, there were six other studies that were found to have dimensions that underlay the capability of IT construct. Sabherwal and Kirs (1994, 1999); Ross, Beath, and Goodhue (1996); Feeny and Willcocks (1998 a, b); Bharadwaj et al. (1999); Byrd and Turner (2000); and Bharadwaj (2000) have suggested dimensions for definition of IT capability. The ensuing dimensions that were put together from all these studies are (1) IT architecture, (2) IT infrastructure, (3) IT Human resource, and (4) IT relationship resource that based on the mentioned literature, we synthesize the following definitions of IT capability dimensions.

\section{- $\quad$ IT Architecture}

IT architecture is a high level map of information and technology necessities of the whole organization, comprised of network, data, and application and technology sub architectures. It offers a vision for how a firm will choose and position its corporate IT resources.

\section{- IT Infrastructure}

We define IT infrastructure as the extent to which applications and data are able to be shared by means of communication networks and retrieved for the use of the organization. 


\section{- $\quad$ IT Human Resources}

In this study, we identify IT human resource as having an understanding of business, planning, problem solving, and technical skills.

\section{- IT Relationship Resource}

We characterize IT relationship resource as not only garnering high levels of respect among the firm and its key business partners including customers, suppliers, and other external collaborators but also achieving excellence in communication, coordination, and negotiation on both sides of the relationship as along with significant shared knowledge about the capabilities of IT and the needs of the business.

\section{Literature on IT capability}

IT capability has become more important in contemporary organizations with the increased emphasis on the strategic role of IT (Bharadwaj, Sambamurthy, and Zmud, 1999). IT studies have revealed that IT capacity helps an organization gain a competitive advantage over its rivals in the business (Bhatt and Grover, 2005; Powell and Dent-Micallef, 1997; Santhanam and Hartono, 2003) and improves the functionality of the organization (Adam and J., 1993; Floyd and Wooldridge, 1990; Quinn, Baily, Herbert, Willett et al., 1994; Santhanam and Hartono, 2003).

Pham and Jordan (2007) studied IT capability along with three components (IT human resource, IT infrastructure, and IT partnership) and tested business performance using data collected in a survey of 140 Australian companies. Of these three components, IT human resource and IT infrastructure were factors affecting business performance while the effect of IT partnership was deemed insignificant. This study was expected to give clarity to methods for enhancement of benefits of IT capability on companies' performance through a comprehension of company resources and the important components.

Recently, Jiao et al. (2008) conducted an empirical study to verify what comprised IT capability. They found four dimensions: IT architecture and routine, IT infrastructure, IT human resource and IT relationship assets. They designated an index system of IT capability. Using a large scale questionnaire study, they examined IT capability's contribution to performance based on 145 valid samples. The findings indicated positive associations between IT capability and a firm's performance. A majority of studies on IT capability are related to its impact on organizational performance.

\section{Research model}

The drivers that enable sustenance of strategic alignment in organizations are very important. Based upon the studies and researches (e.g., Tallon, 2009; Ness, 2005), it can be concluded that strategic alignment is affected by many factors. To name a few: The relationship between IT and business executives, shared domain knowledge, connections between business and IT planning, environmental uncertainty, communication among IT and business executives, IT value management, corporate governance, skill management, relationship management, human resources, and flexibility of IT infrastructure as a response to environmental changes that have of late been frequent in business environments. As stated by Fink and Neumann (2009) business, public, and governmental organizations confronted with various pressures must adjust their strategies, but frequent change cannot be accomplished unless the IT flexibility is able to accommodate it in an efficient and effective manner. As a result, a more flexible IT or IT that has the ability to meet business changes is very crucial to sustaining strategic alignment in business environments today (Bharadwaj, 2000). Past studies have shown that flexibility in IT (i.e., connectivity, compatibility, and modularity) is an influential aspect of sustaining strategic alignment in active and ever changing business settings (e.g., Tallon, 2009; Ness, 2005; Chung, Rainer, Lewis, 2001). Moreover, Chung et al. (2003) studied the links between dimensions of IT flexibility and strategic alignment and argued that connectivity as a dimension of IT flexibility has the most influences on strategic alignment; thus, the researcher will study connectivity with regard to strategic alignment.

A review of literature on factors affecting strategic alignment showed that factors such as shared domain knowledge between IT and business, human resources, IT infrastructure, and IT architecture are important factors that impact strategic alignment (e.g., Tallon, 2009). Further, when reviewing the related literature the researcher noticed that these factors implied and described an important concept: IT capability, because one of the most important definitions of IT capability had been clarified by the dimensions of IT architecture, IT infrastructure, IT human resources (e.g., skills in business and technical areas), and IT relationship resources (described by communications and shared domain knowledge). But in prior researches IT capability has been ignored in relation to strategic alignment that for filling this noticeable gap it is proposed that IT capability (is defined by components of IT architecture, IT infrastructure, IT human Resources, and IT relationship) has a 
positive relationship with strategic alignment. Thus, the researchers proposed the link between IT capability and strategic alignment.

Another key issue is the relationship between connectivity and IT capability is that prior researches have not studied this relationship and we believe this component significantly influence IT capability because of some arguments. For example, connectivity enables information sharing among organizations. Such share ability enables and enhances IT capabilities including IT human resources, because aspects of IT capability entail sharing information between IT and business people and IT relationship management. Thus, we propose the relationship between IT connectivity and IT capability as a link of the conceptual model.

\section{Hypotheses}

\subsection{The relationship between IT Connectivity and IT capability}

Duncan (1995) has defined connectivity as the ability of every part or component of technology to communicate or interact with any other exterior and interior components in the environment of the organization. To put it simply, when all applications, functional areas, persons in the organization are linked to each other, you have connectivity. It has been stressed by Tapscott and Caston (1993) that with IT connectivity, organizations that are flawless and transparent are able to be free from the influence of time and space. It's much easier to share IT resources at the platform level with connectivity. Therefore, the level or communications all through the organization is greatly improved and this makes it easier for users all across the borders of the organization to impart information at fast speed. As a result, our findings imply that connectivity performs a part in the scope of IT capabilities and thus, the following hypothesis is proposed:

\section{H1: Connectivity (as an aspect of IT flexibility) is positively associated with IT capability.}

\subsection{The relationship between IT connectivity and Strategic Alignment}

There are researchers that explain the favourable effect of IT flexibility on strategic alignment, as mentioned by Teece, Pisano, and Shuen (1997), strategic alignment is impacted by the flexibility of information technology. Moreover, there are a few researches that studied dimensions of IT flexibility and strategic alignment. For instance, Chung et al. (2003) tested the relationship between IT flexibility dimensions and strategic alignment using data from 200 US and Canadian medium and large companies. They asked IT personnel to complete a questionnaire relating to compatibility, connectivity, modularity, and IT personnel. Components of IT infrastructure flexibility were found to correlate positively with strategic alignment excluding compatibility. In addition, Chung and colleague argued that IT connectivity has a stronger relationship with strategic alignment than do other dimensions of IT flexibility. Therefore, this has led to the following hypothesis:

\section{H2: Connectivity (as an aspect of IT flexibility) is positively associated with strategic alignment.}

\subsection{The relationship between IT Capability and Strategic Alignment}

As stated earlier, IT capability is defined by dimensions of IT human resource, IT relationship resource, IT infrastructure, and IT architecture. In this study, IT human resources imply vital aspects of technical skills and business for personal. IT relationship resource also implies important aspects such as communication, coordination, and shared knowledge between IT and business. IT infrastructure is defined as the extent to which data and applications can be shared through communication networks and accessed for organizational use and IT architecture is also explained as a high level map of information and technology requirements of the entire firm, composed of network, data and application, and technology sub architecture. Reviewing the literature showed that dimensions (or aspects of dimensions) of IT capability are studied with regard to strategic alignment as explained below.

Shared knowledge between IT and business, communication, and relationship between IT flexibility are important aspects of IT relationship resources and human skills as vital as of IT human resources as well as IT infrastructure and IT architecture have significant relationship with strategic alignment ; thus, the researcher argue that IT capability has a relationship to strategic alignment as illustrated below .

The relationship between business and IT is seen as a vital factor in making strategic alignment possible (Coughlan et al., 2005). It is an even more important fact as pointed out by Luftman and Brier (1999) that when there is not enough closeness in the relationship between IT and business, then, the relationship it becomes a hindrance for alignment.

It has been noted by Teo and Ang (1999) that for successful IT and business alignment, the knowledge business managers have about IT and the knowledge IT managers have about business plays a very crucial role. Kearns and Sabherwal (2007) had in the same way debated that, IT managers would have a chance to take part in 
business planning and vice versa, business managers would take part in strategic IT planning when top level managers started processing IT knowledge. It has been reported by Hussin et al. (2002) that the level of knowledge and appreciation CEOs have with regard to software also affects the alignment process because of the consequent improvement in communications. On the whole, the literature agrees that shared domain knowledge has a positive influence on business and IT alignment.

Alter (2005) and Tan and Gallupe (2006) had similarly agreed that in order for strategic alignment to be successful, good communication between business and IT managers is vital. The maturity of communication is seen by Luftman (2000) as an integral component of the business and IT strategic maturity model. Reich and Benbasat (2000) had likewise suggested in their alignment model that there would be a positive influence on the degree of alignment with good communication coming into play between IT managers and business managers. Reich and Benbasat's case studies on ten businesses altogether, offered them early support for their arguments. Later on, Hu and Huang's (2006) research provided even more support for Reich and Benbasat's case study.

In order to carry out a task that is vital in an organization, the skill needed is the skill to perform processing in an efficient and effective way that is fitting for the particular job. Skills that are gained can come from mentoring, training, and practice. Competency is attained to succeed at a specific job when skills are well sharpened, resulting in improved levels of output and accomplishment for a business (Luftman, 2005).

This distinctive skill or the ability to carry out a given job at a satisfactory level is the most sought after trait that business can encourage for attaining and sustaining competitiveness. Realizing business aims becomes easier when this trait is achieved. As a result of attaining this trait, the time and work spent by an organization can be a significant feature leading to the organization aligning its business to achieve its goals. Skills that involve IT, both in managerial and business aspects has an impact on strategic alignment as shown by some researchers (e.g., Tallon, 2009)

The Strategic Alignment Model (SAM) is one of the research models that have been widely discussed by many scholars. The relationship between the four domains that includes business strategy, IT strategy, IT infrastructure and processes, and organizational infrastructure and processes is described in SAM, which was built by Henderson and Venkatraman (1993). In this model, it is explained that IT infrastructure is one of factors that sustains strategic alignment in organizations.

Overall, as discussed above, factors such as shared knowledge, communication, and relationships between IT and business (aspects of IT relationship resource), skills in IT and business (as an important aspect of IT human resources) and also IT infrastructure have a significant relationship with strategic alignment. Thus, the following hypothesis is proposed:

\section{H3: IT capability is positively associated with strategic alignment.}

\section{Research method}

Data for our study were collected using a questionnaire survey filled up by 82 IT managers of organizations in United Arab Emirates. The researchers measured factors with multiple items. The items were adapted from extant literature to improve the content validity. After the questionnaire was completed, it was first tested among eight IT managers with rich experience. Then we revised some items based on their suggestions to make items easier to understand. The final items and their sources were listed in Table 1.

\section{Data analysis}

Firstly, the researchers performed the PCA (principal components analysis) adopting SPSS and tested whether items could reveal their corresponding factor. Prior to performing the PCA, the researchers measured Kaiser-Meyer-Olkin (KMO) and performed Bartlett's test of sphericity that the findings showed KMO was 0.861 and Bartlett test value was significant at 0.001 . Hence the data were appropriate to perform PCA. The factor loading matrix with varimax rotation was shown in Table 2. Three factors were extracted and they illustrated $88.55 \%$ of the variance. As a result, data had a good validity.

Secondly, the researchers tested the model utilizing SEM software LISREL. The results, as shown in Table 3, indicated that all three hypotheses were supported.

\section{Results}

Table 3 lists all path coefficients and their significance. All hypotheses were supported as stated below.

1. Connectivity has significant positive effect on strategic alignment.

2. Connectivity has also a significant positive effect on IT Capability.

3. IT capability affects strategic alignment. 
The results imply that managers need to improve connectivity more than other factors. Further, the results show that IT connectivity is very important factor both improving IT capability and strategic alignment, consequently IT capability will be improved strategic alignment.

\section{Discussion and Conclusion}

Upon reviewing various literatures on this subject, it was found that IT connectivity is one of the most vital factor that help sustain strategic alignment in today's environments, but unfortunately the studies on this subject is very limited. At present, organizations are looking at IT connectivity as the main and fundamental competency that is required in order for organizations to exist and grow in the environments today. Moreover, reviewing the literature showed that connectivity is one of the most important dimensions of IT flexibility. The researcher upon having a detailed discussion on the possible areas associated to the present body of knowledge has discovered gaps in the studies that have been done on strategic alignment and IT flexibility. This is because; IT capability in relation to IT connectivity (one of IT flexibility components) and strategic alignment has been ignored in the prior studies. To fill this gap, it is argued that IT capability influenced by IT connectivity and influences on strategic alignment. Thus, the researchers examined the relationships among IT connectivity, IT capability, and strategic alignment using a questionnaire survey filled up by 82 IT managers of organizations in United Arab Emirates. The results of the empirical analysis showed that there are significant relationships among the proposed model variables.

As a result, the researcher attempted to develop a model of the relationships among components of IT connectivity, strategic alignment, and IT capability. In the developed model, IT capability is very important and can play key role with regard to IT connectivity and strategic alignment as the research findings will add new knowledge to the existing literature in mentioned factors and to the literature on IT management. Further, extended knowledge will assist organizations to maintain strategic alignment in today's conditions in order to adapt to volatile environments. Therefore, there was an opportunity to extend knowledge in the strategic alignment domain by investigating IT capability factor and its relationship with IT connectivity and strategic alignment.

\section{Limitations}

The present research is concerned with the study of relationships among IT connectivity, strategic alignment, and IT capability. As such, there are many areas for strategic alignment and for further research. In particular, the researcher has found that the study is subject to some important limitations. The first and most important limitation of this study is limited by existing literature. A second limitation concerns the proposals made by this study may require policy decisions and top management support for implementations.

\section{Recommendations}

IT connectivity, as an important area of business strategic needs a lot of research in the developing countries. There is also need to carry out research regarding intrinsic and extrinsic factors which have impact on the IT connectivity. Sector wise research may also be carried out to see the level of IT connectivity and IT capability in different sectors of organizations. On the other hand, further studies with respect to impact of IT connectivity and IT capability on strategic alignment by different organizations, are required in this field especially in the developing countries whether it is manufacturing industry or service industry.

\section{References}

Bharadwaj, Anandhi S. (2000). A Resource-based perspective on information technology capability and firm performance: An empirical investigation. MIS Quarterly, 24(1): 169-96.

Bharadwaj, Anandhi S., V. Sambamurthy, \& Robert W. Zmud. (1999). IT Capabilities: theoretical perspectives and empirical operationalization. Paper presented at $20^{\text {th }}$ International conferences on Information Systems, Charlotte, NC.

Bharadwaj, A.S. (2000). a resource-based perspective on information technology capability and firm performance: An empirical investigation. MIS Quarterly, 24, 1, 169-196.

Boar, B.H., AT\&T Bell Laboratories. (1994). Practical steps for aligning information technology with business strategies - How to gain a competitive advantage (1st edition). New York: John Wiley \& Sons, Inc.

Bowman, B.J.; Davis, G.B.; and Wetherbe, J.C. (1983). Three stage model of MIS planning. Information \& Management, 6, 3, 11-25.

Broadbent, Marianne \& Peter Weill. (1997). Management by maxim: how business and IT Managers can create IT infrastructures. Sloan Management Review, 38(3): 77-83.

Brown, I.T.J. (2004). Testing and extending theory in strategic information systems planning through literature analysis. Information Resources Management Journal, 17, 4, 20-48.

Byrd, T. A., \& Turner, D. E. (2000). Measuring the flexibility of information technology infrastructure: Exploratory analysis of a construct. Journal of Management Information Systems, 17(1), 167-208. 
Byrd, T., Turner, D. (2000). Measuring the flexibility of information technology infrastructure: Exploratory analysis of a construct. Journal of Information Systems Management, 17(1), 167-208.

Byrd, T., and Turner, E. (2000). an exploratory analysis of the information technology infrastructure flexibility construct. Journal of Management Information Systems, 17 (1), p. 172.

Byrd, Terry Anthony \& Douglas E. Turner. (2000). measuring the flexibility of information technology infrastructure: Exploratory analysis of a construct. Journal of Management Information Systems, 17(1): 167-208.

Chan, Y.E., Huff, S.L. (1993). Strategic information systems alignment. Ivey Business Quarterly, 51-55.

Chan, Y.E.; Huff, S.L.; Barclay, D.W.; and Copeland, D.G. (1997). Business strategy orientation, information systems orientation and strategic alignment. Information Systems Research, 8, 2,125-150.

Cheney, P.H., D.P. Hale, \& G.M. Kasper.(1989). Information systems professionals: skills for the 1990s. Paper presented at Proceedings of the 22nd Annual Hawaii International Conference on Systems Science.

Chung, S.H.; Rainer, R.K., Jr.; and Lewis, B.R. (2003). the impact of information technology infrastructure flexibility on strategic alignment and applications implementation. Communications of AIS, 11, 191-206.Computer Sciences Corporation (CSC). (2001). Critical Issues in Information Systems Management. Cambridge, MA.

Couger, J.D., G.B. Davis, D.G. Dologite, D.L. Feinstein, J.T. Gorgone, A.M. Jenkins, G.M. Kasper, J.C. Little, H.E. Longenecker, \& J.S. Valacich. (1995). IS '95: Guideline for undergraduate IS curriculum. MIS Quarterly, 19(3): 341-60.

Das, S.R.; Zahra, S.A.; and Warkentin, M.E. (1991). Integrating the content and process of strategic MIS planning with competitive strategy. Decision Sciences, 22, 5, 953-984.

Duncan, N. B. (1995). CapturiOng flexibility of information technology infrastructure: A study of resource characteristics and their measure. Journal of Management of Information Systems, 12(2), 37-57. 195.

Feeny, David F. \& Leslie P. Willcocks. (1998). Re-designing the IS function around core capabilities. Long Range Planning, 31(3): 354-67.

Feidler, K.D., Gorver, V., \& Teng, J.T.C. (1995). an empirical study of information technology enabled business process redesign and corporate competitive strategy. European Journal of Information Systems, 4(1), 17-30.

Fertuck, L. (1992). Systems Analysis and Design: With CASE Tools, Wm. C. Brown Communications Inc., Dubuque, Iowa.

Galliers, R.D. (1993). IT strategies: beyond competitive advantage. Journal of Strategic Information Systems, 2, 4, 283-291.

Gibson, Rick. (1994). Global information technology architectures. Journal of Global Information Management, 2(1): 28-39.

Grant, R.M. (1991). the resource-based theory of competitive advantage: implications for strategy formulation. California Management Review (spring), 114-135.

Henderson, J.C., and Venkatraman, N. (1993). Strategic alignment: leveraging information technology for transforming organizations. IBM Systems Journal, 32, 1, 4-16.

InformationWeek. (1999). Bond the new and the old: enterprise architecture, InformationWeek.

Jarvenpaa, S.L., and Ives, B. (1993). Organizing for global competition: The fit of information technology. Decision Sciences, 24, 3, 547-580.

Kearns, G.S., Lederer, A. (2001). Strategic IT alignment: A model for competitive advantage. Proceedings of the 22nd International Conference on Information Systems.

Keen, P.G. (1991). Redesigning the Organization through Information Technology. Planning Review, 19 (3), 4-9.

King, W.R. (1978). Strategic planning for management information systems. MIS Quarterly, 2, 1, 27-37.

Labovitz, G., Rosansky, V. (1997). the power of alignment: How great companies stay centered and accomplish extraordinary things. NY: John Wiley \& Sons, Inc.

Luftman, J.; Papp, R.; and Brier, T. (1999). Enablers and inhibitors of business-IT alignment. Communications of AIS, 1, 11, 1-32.

Luftman, J.N.; Lewis, P.R.; and Oldach, S.H. (1993). Transforming the enterprise: the alignment of business and information technology strategies. IBM Systems Journal, 32, 1,198-221.

Lee, Denis M S, Eileen M Trauth, \& Douglas. Farwell. (1995). Critical skills and knowledge requirements of IS professionals: A joint academic/industry investigation. MIS Quarterly, 19(3): 313-41. 
Lee TW, Girolami M, Sejnowski TJ. (1999). Independent component analysis using an extended infomax algorithm for mixed sub-Gaussian and super-Gaussian sources. Neural Comput;11:417-41.

Mendelson, H., and Pillai, R.R. (1998). Clockspeed and informational response: evidence from the information technology industry. Information Systems Research, 9, 4, 415-433.

Miles, R.E., and Snow, C.C. (1978). Organizational Strategy, Structure, and Process. New York: McGraw-Hill.

Ness, L.R. (2005). assessing the relationships among IT flexibility, strategic alignment, and IT effectiveness: study overview and findings. Journal of Information Technology Management, XVI (2), 1-17.

Newkirk, H.E., and Lederer, A.L. (2006). Incremental and comprehensive strategic information systems planning, in an uncertain environment. IEEE Transactions on Engineering Management, 53, 3, 380-394.

Piccoli, G., and Ives, B. (2005). Review: IT-dependent strategic initiatives and sustained competitive advantage: a review and synthesis of the literature. MIS Quarterly, 29, 4, 747-776.

Porter, M.E. (1996). What is strategy? Harvard Business Review, 74, 6, 61-77.

Quinn, J. B., and Hilmer, F. G. (1994). Strategic Outsourcing, Sloan Management Review (35:4), pp. 43-55.

Reich, B.H., and Benbasat, I. (2000). Factors that influence the social dimension of alignment between business and information technology. MIS Quarterly, 24, 1, 81-113.

Rockart, John F, Michael J Earl, \& Jeanne W. Ross. (1996). Eight imperatives for the new IT organization. Sloan Management Review, 38(1): 43-56.

Ross, Jeanne W, Cynthia Mathis Beath, \& Dale L. Goodhue. (1996). Develop long-term competitiveness through IT assets. Sloan Management Review, 38(1): 31-33.

Sabherwal, Rajiv. (1999). the relationship between information system planning sophistication and information system success: An empirical assessment. Decision Sciences, 30(1): 137-68.

Sabherwal, Rajiv \& Peeter. Kirs. (1994). the alignment between organizational critical success factors and information technology capability in academic institutions. Decision Sciences, 25(2): 301-31.

Santhanam, Radhika \& Edward Hartono. (2003). Issues in linking information technology capability to firm performance. MIS Quarterly, 27(1): 125-53.

Schilling, M.A. (2000). toward a general modular systems theory and its application to interfirm product modularity. Academy of Management, 25(2), 312-334.

Sullivan, C.H., Jr. (1982). Rethinking computer systems architecture. Computerworld extra, XVI: 5-10.

Tallon, P.P. (2009). how information technology infrastructure flexibility shapes strategic alignment. Planning for information systems, M.E. Sharpe, Inc.

Tallon, P.P., Kraemer K.L. (2003a). Investigating the relationship between strategic alignment and IT business value: The discovery of a paradox. University of California, Irvine. Retrieved March 12, 2004, [Online]Available: http://www.crito.uci.edu/publications/pdf/AlignmentParadox.pdf

Tapscott, D. and Caston, A. (1993). Paradigm shift: The new promise of information technology. McGraw-Hill. New York, NY.

Teece, D.; Pisano, G.; and Shuen, A. (1997). Dynamic capabilities and strategic management. Strategic Management Journal, 18, 7, 509-533.

Teo, T.S.H., and King, W.R. (1997). Integration between business planning and information systems planning: an evolutionary-contingency perspective. Journal of Management Information Systems, 14, 1, 185-214.

Tippins, Michael J. \& Ravipreet S. Sohi. (2003). IT competency and firm performance: Is organizational learning a missing link? Strategic Management Journal, 24(8): 745-61.

Tuli, K.R., Kohli, A. K. and Bharadwaj, S. G. (2007). Rethinking Customer Solutions: From Product Bundles to Relational Processes, Journal of Marketing, Vol. 71, no. 3, pp. 1-17.

Venkatraman, N.; Henderson, J.C.; and Oldach, S.H. (1993). Continuous strategic alignment: exploiting IT capabilities for competitive success. European Management Journal, 11, 2, 139-149.

Ward, J. \& Peppard, J. (2002). Strategic planning for information systems, West Sussex, England: John Wiley \& Sons.p.1.

Weill, P.; Subramani, M.; and Broadbent, M. (2002). Building IT infrastructure for strategic agility. Sloan Management Review, 44, 1, 57-65. 
Table 1. Measurement items

\begin{tabular}{|c|c|c|c|c|}
\hline \multicolumn{2}{|c|}{ Factor } & Item & Item content & Source \\
\hline \multirow{4}{*}{\multicolumn{2}{|c|}{ Strategic alignment }} & SA 1 & $\begin{array}{l}\text { 1. Our organizations change the } \\
\text { goals/objectives of information system (IS) to } \\
\text { changing goals/objectives of the organization. }\end{array}$ & \multirow{4}{*}{$\begin{array}{l}\text { Segars and Grover } \\
\qquad(1999)\end{array}$} \\
\hline & & SA 2 & $\begin{array}{l}\text { 2. Our organizations recognize IT related } \\
\text { opportunities to support the strategic direction } \\
\text { of the firm. }\end{array}$ & \\
\hline & & SA 3 & $\begin{array}{l}\text { 3. Our organizations modify technology to } \\
\text { strategic change. }\end{array}$ & \\
\hline & & SA 4 & $\begin{array}{l}\text { 4. Our organizations evaluate the strategic } \\
\text { importance of up-and-coming technologies. }\end{array}$ & \\
\hline \multirow{5}{*}{\multicolumn{2}{|c|}{$\begin{array}{l}\text { Connectivity } \\
\quad(\mathrm{CON})\end{array}$}} & CON 1 & $\begin{array}{l}\text { 1. There is enough flexibility in our systems } \\
\text { to incorporate electronic connections to } \\
\text { outsiders. }\end{array}$ & \multirow{5}{*}{$\begin{array}{l}\text { Tallon\& } \\
\text { Kraemer ,2003c,p.36 }\end{array}$} \\
\hline & & CON 2 & $\begin{array}{l}\text { 2. There is a high level of interconnectivity } \\
\text { between systems. }\end{array}$ & \\
\hline & & CON 3 & $\begin{array}{l}\text { 3. The head office is connected to all remote } \\
\text { offices and mobile staff. }\end{array}$ & \\
\hline & & CON 4 & $\begin{array}{l}\text { 4. An open system network type is made use } \\
\text { of, by our organization in order to enhance } \\
\text { connectivity. (e.g., ATM). }\end{array}$ & \\
\hline & & CON 5 & $\begin{array}{l}\text { 5. Corporate databases are accessed to with } \\
\text { the help of various protocols (e.g., SQL). }\end{array}$ & \\
\hline \multirow{12}{*}{$\begin{array}{l}\text { IT } \\
\text { Capability } \\
\text { (ITC) }\end{array}$} & \multirow{3}{*}{$\begin{array}{l}\text { IT } \\
\text { Architecture }\end{array}$} & ITC 1 & $\begin{array}{l}\text { 1. Information Technology strategies are } \\
\text { uniform through the entire organization. }\end{array}$ & \multirow{3}{*}{ Zhang (2005) } \\
\hline & & ITC 2 & $\begin{array}{l}\text { 2. Both business and technical decisions are } \\
\text { taken after seeking advice from IT and } \\
\text { business managers. }\end{array}$ & \\
\hline & & ITC3 & $\begin{array}{l}\text { 3. Organizational policy planning and } \\
\text { Information Technology planning are } \\
\text { incorporated. }\end{array}$ & \\
\hline & \multirow{3}{*}{$\begin{array}{l}\text { IT } \\
\text { Infrastructure }\end{array}$} & ITC4 & $\begin{array}{l}\text { 1. Data architecture found in our } \\
\text { establishment is suitable. }\end{array}$ & \multirow{3}{*}{ Zhang (2005) } \\
\hline & & ITC 5 & $\begin{array}{l}\text { 2. Computer facilities for IT projects are } \\
\text { found in our establishment. }\end{array}$ & \\
\hline & & ITC6 & $\begin{array}{l}\text { 3. Sufficient flexibility of architecture is } \\
\text { found in our establishment. }\end{array}$ & \\
\hline & \multirow{3}{*}{$\begin{array}{l}\text { IT Human } \\
\text { Resources }\end{array}$} & ITC7 & $\begin{array}{l}\text { 1. Potential IT planning is found in our } \\
\text { establishment. }\end{array}$ & \multirow{3}{*}{ Zhang (2005) } \\
\hline & & ITC 8 & $\begin{array}{l}\text { 2. IT assessment and control procedures are } \\
\text { found in our organization. }\end{array}$ & \\
\hline & & ITC 9 & $\begin{array}{l}\text { 3. Suitability of network architecture is found } \\
\text { in our organization. }\end{array}$ & \\
\hline & \multirow{3}{*}{$\begin{array}{l}\text { IT } \\
\text { Relationship } \\
\text { Resource }\end{array}$} & ITC10 & $\begin{array}{l}\text { 1. We have fine line management support of } \\
\text { IT inventiveness. }\end{array}$ & \multirow{3}{*}{ Zhang (2005) } \\
\hline & & ITC11 & $\begin{array}{l}\text { 2. We have respectable relationship between } \\
\text { line management and IT service providers. }\end{array}$ & \\
\hline & & ITC 12 & $\begin{array}{l}\text { 3. There is a close relationship between the } \\
\text { business management and the Information } \\
\text { Technology department. }\end{array}$ & \\
\hline
\end{tabular}


Table 2. Factor loading matrix with varimax rotation

\begin{tabular}{|c|c|c|c|}
\hline & SA & CON & ITC \\
\hline SA 1 &.$/ 825$ & & \\
\hline SA 2 &.$/ 835$ & & \\
\hline SA 3 &.$/ 842$ & & \\
\hline SA 4 &.$/ 849$ & & \\
\hline CON 1 & &.$/ 855$ & \\
\hline CON 2 & &.$/ 832$ & \\
\hline CON 3 & &.$/ 803$ & \\
\hline CON 4 & &.$/ 819$ & \\
\hline CON 5 & &.$/ 801$ & \\
\hline ITC 1 & & &.$/ 806$ \\
\hline ITC 2 & & &.$/ 799$ \\
\hline ITC 3 & & &.$/ 826$ \\
\hline ITC 4 & & &.$/ 812$ \\
\hline ITC 5 & & &.$/ 832$ \\
\hline ITC 6 & & &.$/ 907$ \\
\hline ITC 7 & & &.$/ 803$ \\
\hline ITC 8 & & &.$/ 865$ \\
\hline ITC 9 & & &.$/ 809$ \\
\hline ITC 10 & & &.$/ 808$ \\
\hline ITC 11 & & &.$/ 832$ \\
\hline ITC 12 & & &.$/ 832$ \\
\hline
\end{tabular}

Table 3. Path coefficients and their significance

\begin{tabular}{|c|c|c|c|c|c|}
\hline Hypothesis & \multicolumn{3}{|c|}{ Path } & Path coefficients & The result \\
\hline H1 & $\mathrm{CON}$ & $\longrightarrow$ & SA &.$/ 455 * * *$ & Supported \\
\hline $\mathrm{H} 2$ & $\mathrm{CON}$ & $\longrightarrow$ & ITC &.$/ 432 * * *$ & Supported \\
\hline $\mathrm{H} 3$ & ITC & $\longrightarrow$ & SA &.$/ 235^{* *}$ & Supported \\
\hline
\end{tabular}

(Note: ***, $\mathrm{P}<0.001 ; * *, \mathrm{P}<0.01$ ) 


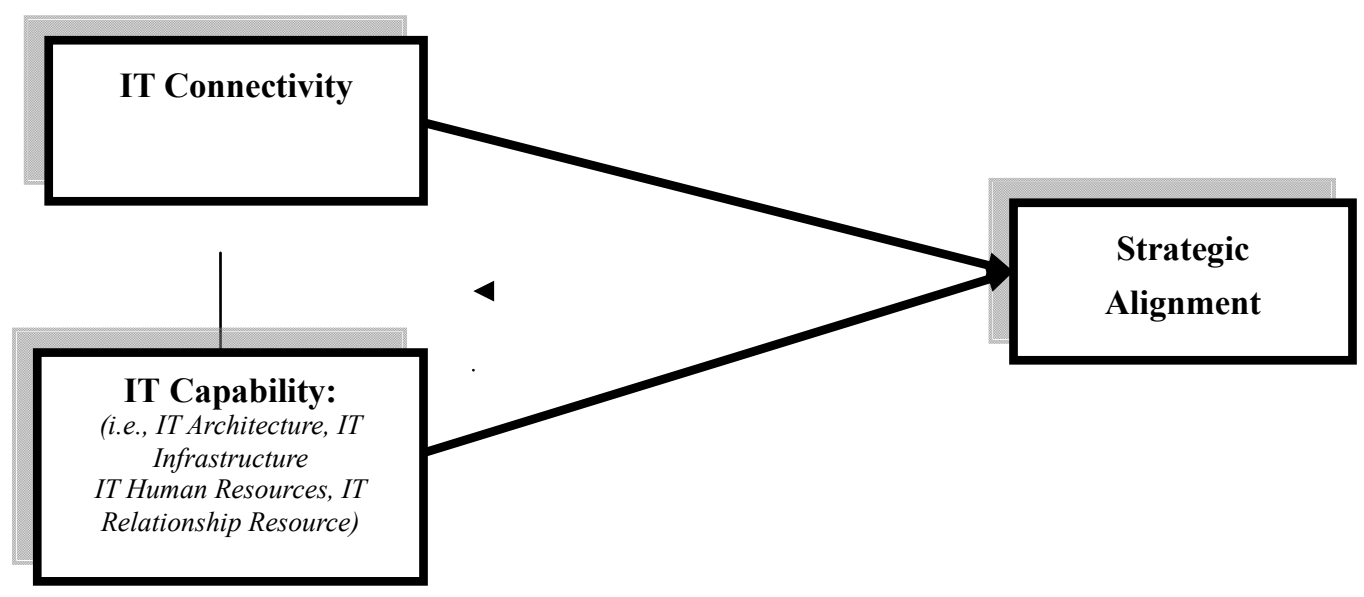

Figure 1. The research model 